\title{
Research
}

\section{From coastal timber supply area to Great Bear Rainforest: exploring power in a social-ecological governance innovation.}

\author{
Michele-Lee Moore $^{1}$ and Ola Tjornbo ${ }^{2}$
}

\begin{abstract}
As the 2005 Millennium Ecosystem Assessment revealed, many social-ecological systems around the world are currently being governed unsustainably. Consequently, social innovation is needed to transform current governance regimes and introduce new more resilient arrangements. Although dominant institutions and social groups may resist such innovations which threaten the status quo and their interests, groups on the margins of the established social order can often trigger governance transformations, despite a lack of conventional financial and institutional resources. In particular, there are numerous cases of marginalized groups initiating processes of radical change to establish sustainable governance practices for threatened socialecological systems. We investigate one such case, and introduce a typology of power developed by Barnett and Duvall (2005) to illuminate the role that nongovernmental organizations and indigenous nations played in the transformation of a socialecological governance regime for an area known as the Great Bear Rainforest, located in British Columbia, Canada. The analysis shows the interplay of compulsory, structural, institutional, and productive forms of power as the four key interest groups in this case enacted the governance transformation. The conclusions draw lessons about how the use and distribution of certain types of power can shape the course and outcomes of social-ecological governance transformations.
\end{abstract}

Key Words: governance transformation; Great Bear Rainforest; power; social innovation

\section{INTRODUCTION}

The understanding of transformations in the governance of social-ecological systems (SES) demands a consideration of the role of power for three main reasons. Firstly, any governance transformation will produce a redistribution of power as different actors and organizations assume new roles, responsibilities, and authority (Dorado 2005, Avelino and Rotmans 2009). Secondly, transforming governance regimes requires a disruption of existing institutions and organizations, with the result that some actors involved are likely to resist the change (see, for example, Parsons 1951, Giddens 1984). Thirdly, in order to achieve the simultaneous processes of disruption and reconciliation associated with governance transformations, those seeking to stimulate transformative change to improve social-ecological governance must find a means of accessing different and often novel sources of power.

Power has served as an analytical lens in numerous areas of study touching on governance (Lukes 1974, Foucault 1980, Keohane and Nye 1989, Cox 1996, Fuchs 2005). Yet, the subject of power rarely appears in the literature on transformation of governance regimes in social-ecological systems (Armitage 2008), making it difficult for practitioners to think strategically about sources and uses of power to create more resilient systems. To help address this research gap, the case of the Central Coast Timber Supply Area (later called the Great Bear Rainforest) in British Columbia (BC), Canada is used to explore the role of power in shaping a transformation in a social-ecological governance regime. The concept of governance transformation or innovation (terms used

\footnotetext{
${ }^{1}$ University of Victoria, ${ }^{2} \mathrm{SiG} @$ Waterloo, University of Waterloo

interchangeably here) refers to governance arrangements in which changes have been made to: a) the sites of authority, b) how financial resources flow, and c) the norms, beliefs, or knowledge base (Westley and Antadze 2010, Nicholls and Murdock 2012).

We begin with a review of the importance of the concept of power to governance discussions, and then introduce a taxonomy developed by Barnett and Duvall (2005) that weaves together two strands in the debate on power and provides a framework for analyzing the empirical findings from the case. Following a description of the research methodology, we explore the emergent and nonlinear dynamics of the Central Coast Timber Supply Area as it was transformed into what is now known as the Great Bear Rainforest, and suggest that the interplay of compulsory, structural, institutional, and productive forms of power helps explain the governance transformation in this case. By marrying analytical concepts from the literatures of global governance and social-ecological systems, we offer insights about the use of power that cut across institutional contexts and drivers of transformations in governance.

\section{The debate about power}

Although power is a contested term and difficult to define (see Lukes 1974, Hay 1997, Arts and Van Tatenhove 2004), the concept remains fundamentally important to analyses of politics, policy, and governance, as well as in many other areas. Some theorists have conceptualized power as actor-centered, with A having power over B when A "can get B to do something that B would not do otherwise" (Dahl 1957:201). Others have argued that power may stem from unobservable 
structural forces such as rules and norms; that is, A creates and reinforces major social structures that perpetuate his or her own power and prevent B from doing what he or she may wish to do (Digeser 1992).

In the scholarship on global governance, definitions and conceptualizations of power have changed over time. The realists believed that material resources, especially economic and military assets, were the basis of individual and state power (Waltz 1999). Later, liberal institutionalists, such as Keohane (2002) and Nye (2008), emphasized the power of institutions to constrain the behavior of states, and the power of states to create and amend these institutions. Meanwhile, constructivists, such as Ruggie (1998) and Wendt (1999), stressed the importance of ideas and the social construction of reality, and the ability of actors to manipulate these. Critical theorists such as Cox (1996) have relied heavily on the ideas of Gramsci (1971) and emphasized that the power of impassive structural forces can define the dominant norms and beliefs of actors in governance arrangements. These different perspectives and lenses have evolved depending on whether scholars are analyzing structures, agents, "power over" or "power to," or the specific types and uses of power.

Less present in discussions of power and governance is the question of how power is used to effect transformations of governance regimes. Several scholars have described the types of power employed by actor groups as they engage in governance activities (Cutler 1999, Price 2003, Fuchs 2005), but these tend to be discussed as distinct from a governance transformation process. Within the literature on social and policy transformations, Avelino and Rotmans (2009) attempted to develop a framework that conceived of power as a capacity of agents to interact with material and immaterial resources in the system, thus emphasizing what power enables actors to "do." However, as the authors themselves recognized, this framework neglects the social structures that may determine which actors have access to power.

In the search for helpful explanatory models of power in social transformations, we borrow from the literature on global governance, and in particular a framework of power developed by global governance scholars Barnett and Duvall (2005), to help explain the power dynamics that can shape a socialecological governance transformation.

\section{The Barnett and Duvall taxonomy}

The schools of thought that have arisen from debates about power need not be treated as choices. Rather, the various conceptualizations may be thought of as alternative lenses, each revealing certain aspects of the operation of power while obscuring others. Based on this premise, the analytical framework selected to study power in the Great Bear Rainforest case was intended to be inclusive of multiple perspectives. Barnett and Duvall's (2005) typology highlights several different aspects of power as well as focusing on the dynamics of power, making it useful for analyzing a process of governance transformation. Here, we introduce this framework and explore how it fits within the broader debates on power.

The typology created by Barnett and Duvall (2005) highlights two separate analytical dimensions as being core to the concept of power: "kind" and "specificity." The first dimension considers that power can be an attribute of specific actors and their interactions, or it can involve the social relations that create or constitute identity, and the capacity of actors to determine their own circumstance (Barnett and Duvall 2005). The second dimension, specificity, refers to the degree to which the social relations through which power operates are "direct and socially specific or indirect and socially diffuse" (Barnett and Duvall 2005:43). Pairing these two dimensions creates a typology of four kinds of power: compulsory, institutional, structural, and productive (Fig. 1).

Fig. 1. Taxonomy of power (adapted from Barnett and Duvall 2005).

\section{Relational specificity}

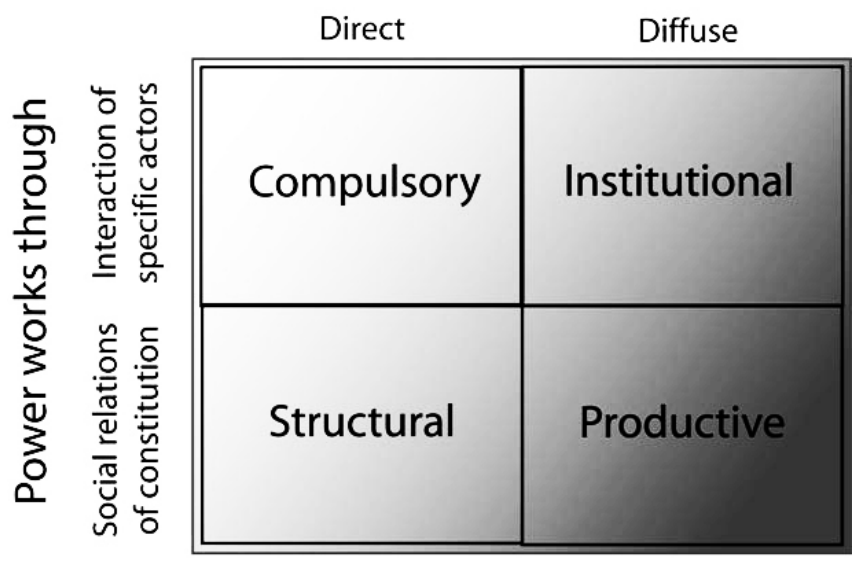

Expanding on the four components of Barnett and Duvall's (2005) taxonomy of power: (1) “Compulsory power" involves a direct, intentional interaction between specific actors and the deployment of resources to achieve a specific goal. Resources may be material, but also may be symbolic or normative, as in, for example, the resources marshaled by nongovernmental organizations (NGOs) to "name and shame" states and corporations into altering their policies (Khagram et al. 2002, Price 2003, Betsill and Corell 2008). "Institutional power" involves individual actors controlling others indirectly through rules and procedures. For example, long established institutions tend to create rigid configurations of rules and processes that shape actors' choices over time. Indeed, outdated institutional designs where power is frozen in ways 
that may no longer be relevant eventually provoke calls for reform, as is the case for global governance institutions such as the United Nations Environment Programme (Biermann 2000, Najam et al. 2006, Young 2008). (3) "Structural power" refers to the ways in which relations and interactions between structural positions can affect the social capacities and interests of individuals. Understood in this way, structural power can affect actors by a) generating asymmetrical social privilege, which is expanded here to also include economic and environmental privilege based on the work of scholars such as Shiva (1993), Miller (1995), and Anand (2004), and b) by shaping actors' self-understanding and subjective interests. (4) "Productive power" is the constitution of relations through knowledge and discourse, essentially echoing the work of Foucault (1980) and capturing the argument put forward by constructivists engaged in debates about power (see Digeser 1992). For example, the dominance of certain ideas and discourse in the international arena, like those associated with neoliberalism and market-based paradigms, constrains the options available to both states and nonstate actors and is viewed as a form of productive power (Strange 1996).

This taxonomy provides a promising framework for considering the multiple kinds of power and multiple relations which unfolded in the social-ecological governance transformation being studied here.

\section{METHODOLOGY}

\section{Data collection and analysis}

The data used in this analysis were derived from earlier studies of the case and include both primary and secondary sources. The collection of primary data took place in 2008 and 2009 through a series of 10 open-structured qualitative interviews, based on methods described by Kvale and Brinkmann (2009). Representatives from each of the four major interest groups were interviewed: provincial government, industry, environmental nongovernmental organizations (ENGOs), and First Nations. The names of interviewees have been omitted to preserve confidentiality; however, references to organizational types are provided where relevant. Interview participants were drawn from the following groups and organizations: Coastal First Nations, Forest Ethics Canada, Greenpeace Canada, BC Ministry of Forestry, Mines, and Lands, Packard Foundation, Sierra Club of BC, and Weyerhaeuser. A document analysis was conducted, including a review of scholarship related to the case, meeting reports of land use planning groups, published campaign materials, and newspaper reports that allowed researchers to verify the details of the transformation through the perceptions of local and national media.

Applying the two dimensions of the Barnett and Duvall (2005) framework systematically, the interview data was first analyzed to identify relationships between one group and another, and between one group and the larger social system. Then the relationships were characterized as to whether there was a direct influence of A on B, or an indirect effect. Each of those interactions was further analyzed for whether or not it involved the direct application of resources to change behavior, formal institutions, structural relationships, or beliefs, norms, or knowledge. Data could then be respectively categorized as interactions of compulsory, structural, institutional, or productive power. Finally, data were organized chronologically to demonstrate how the nature and use of power by different groups shifted over time. This exercise was conducted by each author separately to ensure inter coder reliability. Table 1 presents selected quotes by members of the different groups relating to the different the types of power, organized chronologically.

\section{Case study background}

The case focuses on a coastal temperate rainforest, previously known as the Central Coast Timber Supply Area, located on the western coast of British Columbia, Canada. The forest stands in this region are one of the world's largest remaining intact temperate rainforests (Clapp 2004). Aside from their ecological significance, these forests have played a vital role in the economic history of BC (Braun 2002), where resource extraction industries have been an economic mainstay. Since 1896, approximately $90 \%$ of the province's land has been defined as Crown land and roughly half of that land has been leased to timber companies (Smith et al. 2007, Howlett et al. 2009). The companies that were active in the region at the time of the governance transformation included Western Forest Products, International Forest Products, BC Timber Sales, Howe Sound Pulp and Paper, and Catalyst Paper.

Before the Great Bear Rainforest campaign, two actors more or less monopolized the governance of the forest: the provincial government and the forest industry. The province's reliance on the revenues from lease agreements with the forest industry, and related economic spin-offs, made it difficult for them to consider other arrangements. Local communities depended on the forestry sector as a source of employment, and many employee unions supported existing forestry practices and employment conditions (Wagner 2001).

However, two groups objected to the arrangement between the provincial government and the forest industry. Indigenous nations had for many years challenged the government's right to declare the forest as Crown land, given that much of the Central Coast Timber Supply Area formed part of their traditional territories. The rights and title claims of the indigenous nations were pursued in the provincial and federal courts, and after decades of legal battles, indigenous nations across the province began to win some significant victories within their fight to reclaim their traditional territories (for example, see R. v. Sparrow 1990, and Delgamuukw v. British 
Table 1. Sample of selected quotes coded to power framework. Examples are listed chronologically.

\begin{tabular}{|c|c|c|c|}
\hline Examples of compulsory power & Examples of institutional power & Examples of structural power & Examples of productive power \\
\hline $\begin{array}{l}\text { "The environmentalists come in and } \\
\text { start waving placards and blockading } \\
\text { logging operations." } \\
\text { "You could use the threat of the fact } \\
\text { that you were going to start targeting } \\
\text { a company to get the CEO into the } \\
\text { room pretty quickly and early on." } \\
\text { "We were making decisions about } \\
\text { publicly owned land, and the model } \\
\text { in those days was 'We're the } \\
\text { government, we're the landlord, we } \\
\text { own the land. You're the company, } \\
\text { when we say log, you log,' and 'How } \\
\text { dare you make these decisions about } \\
\text { publicly owned resources?" " }\end{array}$ & $\begin{array}{l}\text { "You had this ENGO/forestry side } \\
\text { table which was kind of doing all the } \\
\text { major deals away from the table and } \\
\text { just reporting." } \\
\text { "Because over the time of this project } \\
\text { there were significant cases and legal } \\
\text { decisions that got made and every } \\
\text { time they got made around First } \\
\text { Nations it actually strengthened the } \\
\text { relationship requirement with First } \\
\text { Nations." }\end{array}$ & $\begin{array}{l}\text { "And then the local communities got } \\
\text { really mad there was an angry } \\
\text { coalition...they were the north island } \\
\text { communities where a lot of the } \\
\text { loggers would come from....and they } \\
\text { said how dare you do this and affect } \\
\text { our employment." }\end{array}$ & $\begin{array}{l}\text { "A number of businesses, certainly } \\
\text { on Vancouver Island and up the } \\
\text { coast, became Greenpeace- free } \\
\text { zones and there was a period of about } \\
\text { a year that Greenpeace was called the } \\
\text { enemy of the province by the premier } \\
\text { at the time." } \\
\text { "This whole issue of how you } \\
\text { manage a commercial forest for } \\
\text { biodiversity was kind of bursting into } \\
\text { bloom. It was one of the flowers } \\
\text { from Clayoquot." } \\
\text { "One way to change attitudes is when } \\
\text { everybody's back is up against the } \\
\text { wall." }\end{array}$ \\
\hline
\end{tabular}

Columbia 1997). To strengthen their efforts to resist forestry practices in the central coast region, the indigenous nations of the region formed a coalition, referred to as "Turning Point" and later changed to "Coastal First Nations." Here, references to First Nations therefore refer to the nations that formed the Coastal First Nations group, including Wuikinuxv, Heiltsuk, Kitasoo/Xaixais, Nuxalk, Gitga'at, Haisla, Metlakatla, Old Massett, Skidegate, and Council of the Haida Nation.

Also actively opposing the provincial government and the forest industry were a number of ENGOs that were convinced that the forestry practices of several companies threatened the survival of the old growth coastal temperate rainforests and, thus, wanted logging and clearcut practices halted. During the 1990s, the ENGOs, in partnership with some indigenous nations, embarked on a highly visible campaign against logging in another part of British Columbia, Clayoquot Sound on the west coast of Vancouver Island, which was dubbed the "war in the woods" by the province's media (Cashore et al. 2001, Howlett et al. 2009). In 1993, tensions in Clayoquot Sound culminated in the largest mass arrest in Canadian history: 10,000 protestors were dispersed by police in order to allow logging to continue (Braun 2002, Rossiter 2004, Smith et al. 2007).

The consequences of the Clayoquot Sound protests rippled throughout the province during the mid-1990s. Although Clayoquot Sound itself represented only a small portion of the provincial lands involved in forestry activities, the provincial government was anxious to ensure that these issues would be better addressed in the remaining areas. They embarked on a land use planning process that included the Central Coast
Timber Supply Area. The Land and Resource Management Planning (LRMP) initiative was envisaged as a consensus based process that would bring together all of the governments (provincial, local, and First Nations) and key stakeholders. But the provincial government also gave assurances that logging would continue, and that a maximum of 2-3\% of the land base could be designated for protection (Tjornbo et al. 2010). The Coastal First Nations refused to participate except as observers, in light of their pursuit of land claims through legal means. The ENGOs, frustrated by the limitation on forest protection, simply stopped participating. By 1997, although the LRMP process was seemingly underway, in reality it was stalled.

The ENGOs devised a campaign directed at international markets to leverage a growing, global pro-environmental sentiment that followed from conferences such as the UN Conference on the Environment and Development held in Rio de Janeiro in 1992. Groups such as Greenpeace, ForestEthics, and the Sierra Club of BC targeted international buyers of wood logged in the Central Coast Timber Supply Area. Companies including Ikea, Staples, and Home Depot experienced a virtual online boycott as well as more traditional storefront demonstrations (Clapp 2004, Howlett et al. 2009, Dempsey 2011). The cancellation of contracts by over 80 companies, and in key emerging markets such as Japan, had a significant impact on forestry operations (Riddell 2005, Riddell et al. 2012).

Thus, while the provincial government and the forestry companies attempted to continue with the LRMP process, it became increasingly clear that the Coastal First Nations and 
ENGOs could not be ignored. This prompted the forestry companies to start negotiating separately with both groups, away from the LRMP process. A coalition of ENGOs and forest-industry representatives came together in an informal organization known as the Joint Solutions Project, which soon began to work with the Coastal First Nations. The groups began to forge an agreement to shape a new future for the central coast forests, and eventually brought this back to the LRMP planning process for approval by the provincial government and other stakeholders.

Five key points were contained in the agreement, which established that: (1) The indigenous nations of the region had a legitimate claim to authority in their traditional territory, and future negotiations with the province would be carried out on a government-government basis. This represented a substantial change in the nature of the relationship between the provincial government and First Nations, and in the authority for governing the social-ecological system in the region. (2) Land use in the forest would be anchored in ecosystem-based management (EBM) practices, meaning that decisions about land use would seek to ensure the smallest possible risk to the ecosystem. This was a radical shift in practice given that the area had historically been managed only for timber value and not in the interests of broader ecosystem values and services. (3) A network of protected areas would be established as a step in implementing EBM. (4) A group of scientists deemed acceptable to all four parties would be responsible for developing EBM guidelines for land use. The Coastal Information Team was significant because it addressed the ongoing conflicts surrounding the science and evidence of ecological impacts from forestry activity. The team provided a neutral authority for integrating the science into management decisions, and for establishing the new norms that would become associated with EBM practices. (5) A new $\$ 120$ million (CAN) fund (known as CIII) would be created to help diversify sustainable economic activities for the region, with special emphasis on creating economic opportunities for the Coastal First Nations.

This five-point agreement is now being implemented and marks a transformation in the governance of the forest's social-ecological system. Yet, although scholars have noted that power changed during the governance transformation (for example, Howlett et al. 2009, Price et al. 2009), there has been no analysis of the dynamics and types of power that shifted as this governance innovation emerged. The Barnett and Duvall (2005) framework provides a precise tool for analyzing the different forms of power that underpinned the governance transformation, and the way in which different actors used power to both drive and resist the change as it emerged.

\section{IMPACTS ON THE DISTRIBUTION OF POWER}

Here, we will first examine how the governance transformation process led to a redistribution of power, and then examine the strategies and types of power that was used to trigger the governance transformation. The goal is to show how both transformation impacts power, and power impacts a governance transformation.

\section{Compulsory power}

An actor who has compulsory power can dictate how another individual should behave, using either material resources or resources that carry a symbolic significance (Barnett and Duvall 2005). At the beginning of the central coast struggle, the provincial government and the forest industry possessed the majority of these resources. The government declared ownership of the land and exercised control over where the forestry companies deployed their material resources in the form of machinery and forestry crews.

Historically, although short on material resources, the ENGOs possessed compulsory power in the form of committed activists determined to bring an end to clear-cut logging in Clayoquot Sound. Activists physically blocked forestry service roads and were successful in temporarily bringing certain operations to a halt, and in this way used a direct, intentional form of power to achieve results. The First Nations throughout BC had a history of using compulsory power when they occupied land that they claimed as part of their traditional territory. In 1995, a standoff near Gustafsen Lake ended in a confrontation between members of the Secwepemc Nation and armed police (Shrubsole 2011). Ultimately, the "war in the woods" produced a stalemate, as neither side possessed sufficient compulsory power to impose its will entirely. Although the provincial government maintained control over the land and forestry activity continued, both parties were moved to pursue an alternative strategy for the central coast.

Things changed dramatically after 1997 through the decisions in the courts and with the establishment of the Joint Solutions Project. The provincial government was obliged to accept the Coastal First Nations as equal partners in the LRMP process. For their part, the ENGOs were able to push the government to agree to drop the $2-3 \%$ limit on protected lands and to establish a moratorium on logging in key valleys as a condition of returning to the LRMP. Further evidence of the compulsory power of ENGOs to mobilize material resources was demonstrated later in the process when they raised $\$ 60$ million dollars (CAN) in private money to help create the sustainable economic development fund (CIII) highlighted in the 2001 five-point agreement.

After 2001, the ENGOs and Coastal First Nations were able to access a significant new symbolic resource in the form of the five-point agreement itself, which today is used to hold the government to account for its commitments to the region. The agreement also ensured that the transformation in governance had durability, regardless of changes in organizational or political leadership. As one ENGO participant noted: "I think when the new government came in, in 2001, they took a look 
and actually, I think they wanted to kill the whole works! But they realized that would be very hard to do now, and so they kept it all going."

\section{Structural power}

Structural power is produced and reinforced through the social positions and relations of different groups within a governance system, and is difficult to manipulate once established. For example, an actor in a hierarchically superior position within an organization is able to constrain the actions of an individual in a lower position within the hierarchy (true of many employer-employee relationships). The changes to structural power and positions are very visible in the governance transformation under study. Yet, without the Barnett and Duvall framework, structural power could easily be confused with compulsory power and its use of material resources.

Before the struggle on the central coast, the governance arrangements gave the provincial government structural power to determine how land could be allocated, thus enabling it to directly constrain the actions of others in the region. The result of this structure was that the benefits of the central coast forests were not shared equally among actors within the region. ENGOs and First Nations were not present within established governance structures and did not benefit from the extraction of the forest's resources. Yet, by the end of the struggle, the ENGOs were included within formal governance structures such as the LRMP table, which provided a substantive change in their structural position within the governance arrangement. Likewise, the government had acknowledged the authority of the Coastal First Nations. As other actors gained power, the forest industry came to believe that the provincial government was incapable of protecting its interests from incursions by the ENGOs and First Nations. As one industry participant commented: "All of a sudden, people weren't playing their role, their appropriate, designated, historical role, and there was role confusion."

The structural power shifts involved the redistribution of governance authority. For example, the five-point agreement required that all signatories of the agreement play a role in the implementation of ecosystem-based management, giving each a more equal structural position in the governance arrangement than existed previously. However, as described earlier, outside of this agreement, the government carried out its own, separate negotiations to settle the land claims of the Coastal First Nations. These government to government negotiations have lead to a piecemeal approach to land use planning where, although it still conforms to ecological principles, it does not fall under the purview of the newly established, multistakeholder Coastal Information Team. Overall then, the picture at the end of the campaign is still one of structural uncertainty, as different groups settle in to new roles. Thus, the impacts of the governance transformation on structural power are yet to be fully known.

\section{Institutional power}

Institutional power flows from the rules and processes defined by institutions to guide and constrain how actors may act (Barnett and Duvall 2005). At the beginning of the central coast struggle, the provincial government held most of the institutional power in the region through its ability to create laws, establish tenure agreements, and regulate the institutions that have formal authority in the region. The forest industry was protected by its lease agreements with the government, and thus also held considerable institutional power. At this time, the Coastal First Nations and ENGOs lacked any formal institutional power that would have influence on the government or forest industry's actions.

After 1993, this situation shifted somewhat as the government formally invited the First Nations and ENGOs to join the LRMP; however, as stated earlier, it attempted to maintain control over the institutional arrangements by setting limits on this process, such as the 2-3\% maximum for protected areas. The first step in weakening this monopoly was the successful 1997 Delgamuukw v. BC court challenge by other BC First Nations which reinforced earlier decisions granting indigenous nations a formal role in resource management decisions and recognized that oral history was a legitimate means to define traditional lands. Equally important was the emergence of informal institutions, such as the Joint Solutions Project and the Coastal First Nations, which, although they lacked formal legal authority, nevertheless became important spaces for negotiations. These informal institutions appeared to some participants to undermine the authority of the LRMP. A government staff member who was responsible for articulating the provincial government's position to the LRMP planning table reflected on the confusion that these informal arrangements created, when some staff were involved in the informal institutions and some staff were still involved in the formal LRMP process, recalling: "A senior official at the Ministry of Forestry was part of those discussions [Joint Solutions Project] so it was a little awkward for us [government staff] because we're the government team, right...it's a senior person we had no control over."

Through the 2001 five-point agreement, a number of new institutions with the power to set rules and processes were created, helping to solidify the shift in institutional power. The Coastal Information Team represented a new "regime" for integrating science into decision making, and the sustainable development fund known as the CIII was established (Smith et al. 2007, Tjornbo et al. 2010). Given that institutional power is more diffuse than structural power, the ENGOs and First Nations gained power from guidelines on implementing ecosystem-based management, or from the conditions associated with the distribution of the CIII funds, rather than from increased authority within the Coastal Information Team. However, the institutional shifts in power did not occur without contestation. For example, the government and 
ENGOs had different interpretations of the strength of the provincial government's commitment to the EBM handbook that provided guidelines for implementing ecosystem-based management. As a government staff member reflected: "We were being pressured to adopt the handbook and we were saying 'we never did adopt the handbook. The [planning] tables never did'." The contestation is ongoing for the Coastal First Nations, as 25 separate nations continue to negotiate their own agreements bilaterally with the provincial government.

\section{Productive power}

Productive power is the diffuse power that stems from being able to shape, influence or embed ideas, knowledge, norms, and discourse. Shifts in the perceptions of forestry practices and the logging of old-growth forests were occurring internationally during the time of the Great Bear Rainforest campaign. In 1992, the Rio Earth Summit put environmental issues and, in particular, the destruction of rainforests, firmly on the global agenda. In fact, many of the members of ENGOs active in $\mathrm{BC}$ during that time had gained experience from working on similar campaigns in South American rainforests. It is likely this helped them muster support for the Clayoquot blockade, but they still did not hold the majority of the productive power in early 1992. The central coast area had relied on forestry activity for its local economy for a long time. Consequently, a great deal of hostility was initially directed at the ENGOs by local communities, both indigenous and nonindigenous. During the Clayoquot Sound campaign, there was widespread disdain shown towards the environmentalists. The Premier of BC branded the ENGOs "enemies of the state" and many local residents joined in creating "Greenpeace-free zones." The belief that ENGOs were troublemakers persisted throughout the Great Bear Rainforest campaign, even when they eventually began to negotiate with the forest industry. The fact that the industry engaged in the negotiations led to widespread outrage. A key negotiator from the forest industry remembers being burned in effigy by locals angry at what they saw as collusion with the ENGOs. The locals sided with the government, as is evident in the comment of a forest industry participant: "The model in those days was: 'We're the government, we're the landlord, we own the land. You're the company, when we say log, you log,' and 'How dare you make these decisions about publicly owned resources?'”

Recognizing, at least implicitly, that compulsory power was insufficient to halt forestry activities, the ENGOs drew upon their sources of productive power. To leverage global trends in their favor, the ENGOs launched the international markets campaign described in the previous section (see also Clapp 2004, Howlett et al. 2009, Dempsey 2011). They realized that the forest industry, although it enjoyed considerable support at home because of the local employment and economic benefits, was vulnerable to negative publicity internationally where most of the wood was sold. During this time, the ENGOs also adopted the term "Great Bear Rainforest" and used images of the Kermode or "Spirit" bear as a visual representation of the values in the forest ecosystem that they deemed worth protecting, which proved to be an effective tactic for exercising productive power. Rossiter (2004) argued that it helped create a discourse about the forest ecosystem that fit with urbanites' vision of pristine nature. The result was a reframing of the values associated with the area, from an almost sole focus on timber supply resources to the incorporation of other ecological values.

The shift in productive power was evident in the fact that the provincial government and forestry companies began to adopt the language of the reframed "Great Bear Rainforest," thereby acknowledging the forest's inherent ecological values. Further evidence was the formation of the Coast Forest Conservation Initiative by the five companies most active in the area. Although the adoption of new framing and discourse can be discredited as "greenwashing" if actions do not follow, it is a useful indicator of the productive power that the ENGOs and Coastal First Nations had gained.

\section{STRATEGIES OF POWER}

Just as governance transformations involve an eventual redistribution of power, they also require the use of power to occur. Summarizing the strategies that different actors used, which either maximized their limited power or undermined their previously ample power, adds depth to the understanding of the social-ecological governance transformation.

The ENGOs began their campaign by deploying compulsory power in the form of physical blockades. Although this strategy was partially successful, the ENGOs never had sufficient resources to obstruct the forest industry altogether. Shifting to an alternate strategy, the ENGOs leveraged the productive power of the global environmental movement and used that to gain structural power as a result of the international markets campaign. These strategies alone may not have been enough to lead to the creation of the five-point agreement. However, as their forest industry opponents began to negotiate with them, the ENGOs continued to adroitly employ their productive power, but this time to frame the ecosystem-based management approach to the Great Bear Rainforest as a winwin solution.

The Coastal First Nations, like the ENGOs, had only marginal power in the governance arrangement at the beginning of the struggle on the central coast, but ended with greater power in three categories by using strategies quite different from those of the ENGOs. The Coastal First Nations relied primarily on formal legal channels to secure new sources of institutional and structural power. As key court decisions in British Columbia created important legal precedents, it became clear that the government, forest industry, and ENGOs would have to negotiate with the Coastal First Nations if they were interested in working in the Coastal First Nations' traditional territories. The Coastal First Nations also drew upon their 
productive power to emphasize the ecological values of the Great Bear Rainforest, reinforcing the ENGOs efforts. Since that time, the First Nations in the region have continued the process of institution building in concert with government begun in 2001, as part of their government to government approach. It remains unclear what outcomes will follow from this process, but the indigenous nations of the Coastal First Nations coalition have acquired further structural and institutional power.

Without the application of Barnett and Duvall's (2005) typology, such differences between the ENGOs and First Nations would be much harder to discern and qualify. Although the outcome of achieving a different structural position within the new governance arrangements was similar for both groups, how and why this occurred is illuminated by an understanding of the interplay of different forms of power at work for each group.

The forest industry could initially exercise all four forms of power in the Central Coast Timber Supply Area. However, the industry had faced a decline in business since the early 1990s because many productive stands elsewhere in the province had been logged (Price et al. 2009), and as a result of the increasing value of the Canadian dollar (Wagner 2001). These conditions, combined with the new forms of power acquired by the Coastal First Nations and the ENGOs, led the industry groups to realize that simply breaking through ENGO and First Nation blockades was unlikely resolve the conflict. As one ENGO representative noted: "[There] were critical players within industry who just said, 'We have to change this. We're not going to win this. We can't win this by simply firing missives back to the environmental groups." The forest industry's to withdraw its support from the provincial government's LRMP process may have appeared surprising, given that the restrictions on protected areas imposed by governments worked in favor of the industry. But it was a strategic use of institutional power to reset the "rules" of the forest through informal channels.

The provincial government appeared largely opposed to the cause put forth by the First Nations and ENGOs in the central coast struggle, as evidenced by their moves to break the blockades and reinforce the existing institutional order within the governance system. Although the LRMP process could have been designed to ensure procedural equality and an increase of institutional power for other actors, the provincial government attempted to keep fairly tight control over the process and placed strict limits on the amount of protected land that could be created, with the consequence that the ENGOs and First Nations refused to participate for fear of being co-opted. As one ENGO member stated, "The government itself characterizes any decision that come out of the process-even if it is not a decision that you happen to agree with—as one that has everybody signed up." The provincial government also attempted to use their institutional power to directly undermine the ENGOs, for example by revoking Greenpeace Canada's charitable status.

Yet, in trying to resist change through the use of institutional and structural power, the government instead undermined its power. In particular, the LRMP temporarily lost legitimacy and alternative, informal institutions, where government had a much less prominent role, became the sites where most of the five-point agreement was negotiated. Ultimately, the productive power of the ENGOs and the new institutional status of the First Nations were key to shaping the direction of change in the Great Bear Rainforest. To some extent, the provincial government's ability to use its power was altered by changes occurring at higher scales. First, the emergence of the global environmental agenda gave impetus to the ENGOs' campaign, and then came the decisions made by bodies such as the Supreme Court. However, by accepting the new ecological values-based framing provided by ENGOs and the Coastal First Nations, as well as the new government to government status of First Nation negotiations, the government found a strategy that maintained its institutional and structural power for the long term. Since then, the provincial government has become an important player in the implementation of the 2001 five-point agreement.

\section{CONCLUSION}

It is widely acknowledged that the governance regime for the Great Bear Rainforest was transformed. The analysis presented here has demonstrated how that shift occurred and what the transformation involved, including moving from a regime in which the formal authority rested solely with the provincial government and preference was given to the forest industry to one founded on the principles of ecosystem-based management. The results are newly configured relationships for government, Coastal First Nations, the forest industry and ENGOs. Each of the social structures contained in the definition of a governance innovation used here, including authority, financial resource flows, and norms and beliefs, were altered in this case. The power typology of Barnett and Duvall (2005) adds depth to the understanding of the transformation process involved for those social structures, in which all four types of power-compulsory, institutional, structural, and productive-were both strategically employed and subsequently affected. In particular, the two groups that were not included in the formal governance arrangements initially were able to employ productive and institutional power to make gains in structural power. The analysis also illustrated that groups that use compulsory power to resist governance transformation will not be successful.

Despite the gains in different forms of power by the ENGOs and Coastal First Nations, concluding that the provincial government and forest industry lost that same amount of power would be inaccurate. As the Great Bear Rainforest began to 
be recognized internationally for its ecosystem-based management, biodiversity protection, sustainable economic development, and inclusive governance arrangements, the provincial government and the forest industry were understood to be part of the collective effort that achieved that transformation and improved the social-ecological governance of the region. This recognition has ensured that at least some of all four types of power are still held by the industry and that the provincial government has maintained much, if not all, four types of power inherent to government.

Previous research that explored the Great Bear Rainforest by Price et al. (1999) characterized the shift in power as moving from government to First Nations (Price et al. 2009), implying that only one type of power was involved. In applying the typology of power originally developed by Barnett and Duvall (2005) in the field of global governance, new distinctions in the use of power to transform a social-ecological governance regime could be identified. Although these findings may be specific to the Great Bear Rainforest case, the fact that all four forms of power were central to the transformation is instructive for other studies in social-ecological governance. Future research could explore whether social-ecological governance transformations follow a similar pattern in the types of power used to disrupt existing systems, and test whether certain actor groups are routinely effective or ineffective at employing particular types of power.

Responses to this article can be read online at: http://www.ecologyandsociety.org/issues/responses. php/5194

\section{Acknowledgments:}

This research was supported by the J.W. McConnell Family Foundation. We appreciate the feedback from colleagues and participants at the Berlin Innovation in Governance Forum and the 2011 Resilience Conference on previous versions of this paper.

\section{LITERATURE CITED}

Anand, R. 2004. International environmental justice. Ashgate, London, UK.

Armitage, D. 2008. Governance and the commons in a multilevel world. International Journal of the Commons 2(1):7-32.

Arts, B., and J. Van Tatenhove, 2004. Policy and power: a conceptual framework between the 'old' and 'new' policy idioms. Policy Sciences 37(3):339-356. http://dx.doi. org/10.1007/s11077-005-0156-9

Avelino, F., and J. Rotmans. 2009. Power in transition: an interdisciplinary framework to study power in relation to structural change. European Journal of Social Theory 12 (4):543-569. http://dx.doi.org/10.1177/1368431009349830

Barnett, M., and R. Duvall. 2005. Power in international politics. International Organization 59(1):39-75. http://dx. doi.org/10.1017/S0020818305050010

Betsill, M. M., and E. Corell, editors. 2008. NGO diplomacy: the influence of nongovernmental organizations in international environmental negotiations. The MIT Press, Cambridge, Massachusetts, USA.

Biermann, F. 2000. The case for a World Environment Organization. Environment 42(9):22-31. http://dx.doi. org/10.1080/00139150009605762

Braun, B. 2002. The intemperate rainforest: nature, culture, and power on Canada's west coast. University of Minnesota Press: Minneapolis, Minnesota, USA.

Cashore, B., G. Hoberg, M. Howlett, J. Rayner, and J. Wilson. 2001. In search of sustainability: British Columbia forest policy in the 1990s. University of British Columbia Press, Vancouver, BC, USA.

Clapp, R. A. 2004. Wilderness ethics and political ecology: remapping the Great Bear Rainforest. Political Geography 23 (7):839-862. http://dx.doi.org/10.1016/j.polgeo.2004.05.012

Cox, R. 1996. Approaches to world order. Cambridge University Press, Cambridge, UK. http://dx.doi.org/10.1017/ CBO9780511607905

Cutler, A. C. 1999. Location 'authority' in the global political economy. International Studies Quarterly 43(1):59-81. http://dx.doi.org/10.1111/0020-8833.00111

Dahl, R. A. 1957. The concept of power. Behavioral Science 2(1):201-215. http://dx.doi.org/10.1002/bs.3830020303

Delgamuukw v. British Columbia. 1997. 3 S.C.R. 1010.

Dempsey, J. 2011. The politics of nature in British Columbia's Great Bear Rainforest. Geoforum 42(2):211-221. http://dx. doi.org/10.1016/j.geoforum.2010.12.003

Digeser, P. 1992. The fourth face of power. The Journal of Politics 54(4):977-1007. http://dx.doi.org/10.2307/2132105

Dorado, S. 2005. Institutional entrepreneurship, partaking, and convening. Organization Studies 26(3):385-414 http://dx. doi.org/10.1177/0170840605050873

Foucault, M. 1980. Power/knowledge: selected interviews and other writings 1972-1977. Pantheon, New York, New York, USA.

Fuchs, D. 2005. The commanding heights? The strength and fragility of business power in world politics. Millenium 33 (3):771-802. http://dx.doi.org/10.1177/03058298050330030501 
Giddens, A. 1984. The constitution of society: outline of the theory of structuration. University of California Press, Berkely, California, USA.

Gramsci, A. 1971. Selections from the prison notebooks. ElecBooks, London, UK.

Hay, C. 1997. Divided by a common language: political theory and the concept of power. Politics 17(1):45-52. http://dx.doi. org/10.1111/1467-9256.00033

Howlett, M., J. Rayner, and C. Tollefson. 2009. From government to governance in forest planning? Lessons from the case of the British Columbia Great Bear Rainforest initiative. Forest Policy and Economics 11(5-6):383-391. http://dx.doi.org/10.1016/j.forpol.2009.01.003

Keohane, R. 2002. Power and governance in a partially globalized world. Routledge, London, UK.

Keohane, R., and J. Nye. 1989. Power and interdependence. Second Edition. Scott, Foresman and Company, Boston, Massachusetts, USA.

Khagram, S., J. V. Riker, and K. Sikkink, editors. 2002. Restructuring world politics: transnational social movements, networks and norms. The University of Minnesota Press, Minneapolis, Minnesota, USA.

Kvale, S., and S. Brinkmann. 2009. Interviews: learning the craft of qualitative research interviewing. Sage, Thousand Oaks, California, USA.

Lukes, S. 1974. Power: a radical view. MacMillan, London, UK.

Miller, M. 1995. The third world in global environmental politics. Lynne Rienner, Boulder, Colorado, USA.

Najam, A., M. Papa, and N. Taiyab. 2006. Global environmental governance: a reform agenda. International Institute for Sustainable Development, Winnipeg, Manitoba, Canada.

Nicholls, A., and A. Murdock, editors. 2012. Social innovation. Palgrave MacMillan, London, UK.

Nye, J. 2008. The powers to lead. Oxford University Press, Oxford, UK.

Parsons, T. 1951. The social system. Routledge and Kegan Paul, London, UK.

Price, K., A. Roburn, and A. MacKinnon, A. 2009. Ecosystembased management in the Great Bear Rainforest. Forest Ecology and Management 258(4):495-503. http://dx.doi. org/10.1016/j.foreco.2008.10.010

Price, R. 2003. Transnational civil society and advocacy in world politics. World Politics 55(4):579-606. http://dx.doi. org/10.1353/wp.2003.0024
R. v. Sparrow. 1990. 1 S.C.R. 1075.

Riddell, D. 2005. Evolving approaches to conservation: integral ecology and Canada's Great Bear Rainforest. World Futures 61(1-2):63-78. http://dx.doi.org/10.1080/02604020$\underline{590902362}$

Riddell, D., O. Tjornbo, and F. Westley. 2012. Agency and innovation in a phase of turbulent change: conservation in the Great Bear Rainforest. Pages 155-180 in K. Golden-Biddle, and J. Dutton, editors. Using a positive lens to explore social change and organizations. Routledge, New York, New York, USA.

Rossiter, D. 2004. The nature of protest: constructing the spaces of British Columbia's rainforests. Cultural Geographies 11(2):139-164. http://dx.doi.org/10.1191/14744744004eu298oa

Ruggie, J. G. 1998. Constructing the world polity: essays on international institutionalization. Routledge, New York, New York, USA.

Shiva, V. 1993. The greening of the global reach. Pages 149156 in W. Sachs, editor. Global ecology: a new arena of political conflict. Fernwood, Halifax, Nova Scotia, USA.

Shrubsole, N. D. 2011. The sun dance and the Gustafsen Lake standoff: healing through resistance and the danger of dismissing religion. The International Indigenous Policy Journal 2(4).

Smith, M., A. Sterritt, and P. Armstrong. 2007. From conflict to collaboration: the story of the Great Bear Rainforest. ForestEthics, San Francisco, California, USA. [online]: http:// tarsandsfreecoast.ca/downloads/WWFpaper.pdf

Strange, S. 1996. The retreat of the state: the diffusion of power in the world economy. Cambridge University Press, Cambridge, UK.

Tjornbo, O., F. R. Westley, and D. Riddell. 2010. Case study: the Great Bear Rainforest. SiG@Waterloo, University of Waterloo, Waterloo, Ontario, Canada.

[online]: http://sig.uwaterloo.ca/sites/default/files/documents/ SiG\%20GBRF\%20Web Feb2\%202010.pdf

Wagner, W. L. 2001. Excising the common wealth? A study of public sector intervention in the British Columbia forest industry, 1980-1996. Dissertation. University of Victoria, Victoria, British Columbia, Canada.

Waltz, K. 1999. Globalization and governance. Political Science and Politics 32(4). http://dx.doi.org/10.2307/420158

Wendt, A. 1999. Social theory of international politics. Cambridge University Press, Cambridge, UK. http://dx.doi. org/10.1017/CBO9780511612183 
Westley, F. R., and N. Antadze. 2010. Making a difference: strategies for scaling social innovation for greater impact. The Public Sector Innovation Journal 15(2):2.

Young, O. R. 2008. The architecture of global environmental governance: bringing science to bear on policy. Global Environmental Politics 8(1):14-31. http://dx.doi.org/10.1162/ glep.2008.8.1.14 